QUESTIONS OF FOOD SAFETY IN THE AQUAPONICS
SYSTEMS

\section{ÉLELMISZER-BIZTONSÁGI KÉRDÉSEK AZ AKVAPÓNIARENDSZEREKBEN}

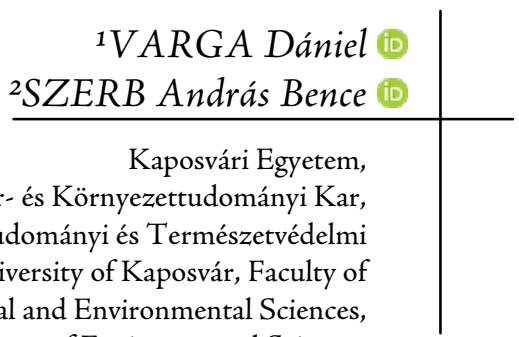 \\ ${ }^{1}$ VARGA Dániel (10) \\ Kaposvári Egyetem, \\ ${ }^{1}$ Agrár- és Környezettudományi Kar, \\ Környezettudományi és Természetvédelmi \\ Intézet (University of Kaposvár, Faculty of \\ Agricultural and Environmental Sciences, \\ Institute of Environmental Sciences \\ and Nature Conservation) \\ ${ }^{2}$ Gazdaságtudományi Kar, Gazdálkodás és \\ Szervezéstudományok Doktori Iskola \\ (Faculty of Economics, Doctoral School of \\ Management and Organizational Sciences) \\ H-7400 Kaposvár, Guba Sándor utca 40.
}

Throughout human history Earth's natural resources and their carrying capacity have been closely linked to different human cultures, their development and their limitations. Due to the demographic explosion from the beginning of the 20th century, the earth's population today exceeds 7.3 billion. Mankind has taken the use of the resources from its environment to a new level which exceeds since the 1970's what the planet can sustainably provide within a year. Rising environmental and human health concerns and growing demand for different use of production set new challenges for agriculture and food production. Aquaponics systems are giving a new perspective for both rural and urban gardeners to increase their production with the use of zero soil and integrate aquaculture (fish farm) and hydroponics. However, food safety issues are rising when people grow plants with the presence of fish culture. This study has been made to answer basic food safety questions valid in the aquaponics production.

Kulcsszavak: élelmiszer-biztonság, akvakultúra, akvapónia, növénytermesztés

Keywords: food safety, aquaculture, aquaponics, plant production

JEL-kód: Q13, Q56

\section{BEVEZETÉS}

Az akvapónia egy recirkuláción alapuló termelési rendszer, amely egy ökológiai körforgásba integrálja a haltenyésztést és a növénytermesztést. A rendszer müködési elve egyszerüen: a haltartályok elfolyó vize, mely a halak által kiválasztott ammóniával terhelt, egy olyan tálcába kerül szivattyúzással, melyben porózus, nagy felületü ültetőközeg van, melynek a felületén nitrifikáló baktériumok élnek. Ezek az ammóniát nitritté, majd nitráttá alakítják. A közegbe ültetett haszonnövények megtisztítják a vizet azzal, hogy felveszik a nitrátot (és más egyéb tápanyagokat). Ezt követően a növények által megtisztított víz visszakerülhet a halakhoz ( $R a$ kocy, 2012). Ez a folyamat lehetővé teszi, hogy a halak, növények és baktériumok kvázi szimbiózisban fejlődjenek, és együtt tartják fenn a rendszer egyensúlyát. Noha a halak és zöldségek előállítása az akvapóniaegységek legszembetűnőbb outputja, alapvető fontosságú megérteni, hogy az akvapónia egy teljes ökoszisztéma irányítása/kontrollálása, amely három fó organizmuscsoportot foglal magában: halak, növények és baktériumok (Engle, 2015).

Az akvakultúrából származó salakanyagok felhasználása a növények tápanyagpótlására már évezredek óta ismert. Több ázsiai és dél-, illetve közép-amerikai civilizáció használta sikeresen ezt a technológiát. A modern akvapóniarendszerek kutatása az 1970-es évek végétől indult meg Észak-Amerikában és Európában, eleinte azonban korlátozott sikerek mellett tudták integrálni a haltenyésztést a növénytermesztéssel (Somerville és mtsai., 2014). A kutatások az 1990-es években a rendszertervezés, biológiai szürés és a különböző hal- és növénykultúrák arányának meghatározására irányultak. Olyan zárt rendszerek kezdtek kialakulni, melyek lehetővé tették a víz és a benne oldott tápanyagok újrafelhasználását a növények növekedése érdekében. Noha az 1980-as évek óta használják számos helyen, az akvapónia továbbra is viszonylag új élelmiszer-termelési módszernek számít, csak kevés kutatási és gyakorlati példa áll rendelkezésre világszerte, Magyarországon pe- 
dig az elérhető források szinte teljesen hiányoznak. A technológiai kutatások főbb gócpontjai a Virgin-szigetek (University of Virgin Islands, USA), Ausztrália, Kanada, Bangladesh (Somerville és mtsai., 2014) és Svájc. Ezek a kutatások fóként a rendszerek technológiai felépítésére, üzemeltetésére, a növényi tápanyagok megfelelő mennyiségére és az egyéb tényezőkre irányultak. Csak nagyon kevés kutatás foglalkozott a közelmúltban az akvapóniát érintő élelmiszer-biztonsági vizsgálatokkal, ezért korlátozott mennyiségü forrás állt rendelkezésünkre. Célunk ezért röviden összefoglalni az akvakultúrával kapcsolatos élelmiszer-biztonsági kérdéseket, kiemelten foglalkozva az akvapóniával mint multitrofikus haltenyésztési-növénytermelési rendszerrel.

\section{PIACI ÁTTEKINTÉS}

Hazánkban az étkezési haltermelés és -fogyasztás egyre fontosabb kérdéskör lett az elmúlt években, hiszen az Európai Unió átlagától lényegesen lemaradt a magyarországi. Étkezési haltermelésünk nem változott jelentősen az 1. táblázat alapján, 21000 és 24000 tonna előállításával, 9000 és 11500 tonna között mozgó exportunk mellett folyamatosan növekvő importadatok figyelhetők meg a közelmúltban, mely 2014-hez képest közel 20\%kal magasabb, 47500 tonna feletti importvolument jelentett.

\begin{tabular}{|c|c|c|c|}
\hline Év & $\begin{array}{c}\text { Étkezési } \\
\text { haltermelés } \\
\text { (tonna) }\end{array}$ & Export (tonna) & Import (tonna) \\
\hline 2014 & 22529 & 9011,03 & 39770,12 \\
\hline 2015 & 23299 & 11483,39 & 45119,77 \\
\hline 2016 & 21558 & 10491,23 & 45265,27 \\
\hline 2017 & 23865 & 9259,60 & 47536,54 \\
\hline
\end{tabular}

Forrás: AKI (2018)

Míg az Európai Unióban $22 \mathrm{~kg}$ körül van az átlagos egy fơre eső halfogyasztás (Bojtárné-Lukacsik E György, 2016), addig hazánkban az utóbbi évek jelentős emelkedése ellenére is alig haladta meg a $6 \mathrm{~kg} /$ fö/évet. Amennyiben hosszabb periódust vizsgálunk, akkor a rendszerváltást követően szolid növekedés volt megfigyelhető 2,7 kg/fó/évről 3,7 kg/fó/évre 2013-ig, majd jelentősebb

\section{1. ábra: Magyarország éves édesvízi- és tengerihal-fogyasztása $\left(\mathrm{kg} / \mathrm{fö}^{\prime \prime}\right)$}

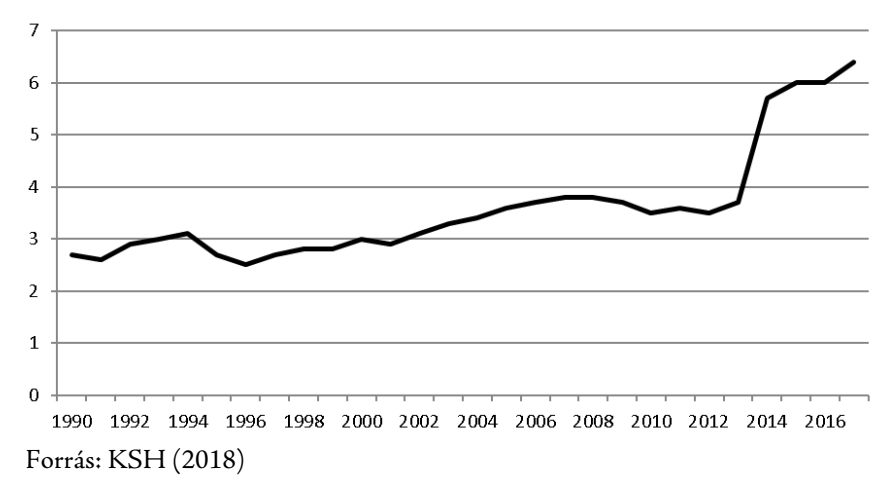

emelkedés 2017-ig bezárólag 6,4 kg/fö/évre, mely elsősorban a halfogyasztás statisztikai módszertani váltásának köszönhető 2014 után. 2014-ben tért át ugyanis Magyarország az Európai Unióban általánosan használt élősúlyra vetített számítási metódusra, mely jelentősen megnövelte a halfogyasztási mutató értékét.

$\mathrm{A} z$ alacsony halfogyasztást befolyásolhatja többek között a lakosság árérzékenysége, ízlése és a termék elérhetősége. Az otthoni feldolgozás körülményessége miatt kevésbé kedvelt húsféle a hal a magyarok között (AKI, 2018). A hazai halfogyasztásra mindemellett nagymértékben jellemző a szezonalitás és az alkalmi jelleg is.

\section{3. ÉLELMISZER-BIZTONSÁG AZ AKVAKULTÚRÁ- BAN}

A halfogyasztás pozitív élettani hatásai elvitathatatlanok, azonban szem elött kell tartani, hogy bizonyos esetekben kockázatot is rejthet az akvakultúra-termékek fogyasztása. Az USA-ban, annak ellenére, hogy a marha és baromfi fogyasztása jelentősen meghaladja a halászati termékek fogyasztását, az élelmiszer-eredetű megbetegedések jelentős részéért a halak és egyéb vízi állatok felelősek (Nickelson, 1998). A növekvő halfogyasztás tehát világ- és hazai szinten is számos élelmiszer-biztonsági kérdést vet fel napjainkban.

A kockázati tényezők közül kiemelendő az édesvízi haltenyésztés esetében az emberi tevékenység (mezőgazdaság, környezetszennyezés), melynek következtében a vizekbe kerülő vegyületek jelentős hatással lehetnek az előállított végtermékre.

\subsection{Algák, ízrontó és ízlelést befolyásoló vegyületek}

A z egész világon problémát jelent az ivóvízben és a halhúsban felhalmozódó kellemetlen iszapíz és dohos, penészes szag. Ez a jelenség ugyan nem jár egészségügyi kockázattal, de jelentős mértékben képes rontani a halhús élvezeti értékét a fogyasztók számára, így a termék minőségére és megítélésére is hatással van. Közvetett módon nagyban befolyásolja a halfogyasztás alakulását is, hiszen sokan emiatt nem fogyasztják szívesen a halhúst. A nem kívánt ízért két izoprén vegyület a felelős. A geozmint (GSM) és 2-metil-izoborneolt (MIB) mikroorganizmusok szintetizálják anyagcseretermékként, vagy pedig a pusztulásuk után kerülnek a vízbe. A geozmint elöször Actinomycetes fajokból mutatták ki (Gerber E Lechevalier, 1965), később cianobaktériumokból is sikerült kimutatni. A kékbaktériumok számos nemzetsége (Anabaena, Aphanizomenon, Lyngbya, Oscillatoria, és Symploca) termel még geozmint (Van der Ploeg E Tucker, 1993). Ezek mellett sugárbaktériumok (sugárgombák) (pl. Streptomyces és Nocardia sp.) is szintetizálják a geozmint és a MIB-et, de egyes kovamoszatok, zöldalgák, sárga moszatok, barázdás moszatok, fonalas gombák is képesek előállítani ezeket a vegyületeket (Kerepeczki és mtsai., 2000).

A halak a vízből főként a kopoltyún keresztül, kisebb mértékben a bőrön át, valamint az ízrontó vegyületeket termelő táplálékszervezetek fogyasztásával veszik fel a MIB-et és a geozmint, melyek azután a zsírban gazdag szövetekben halmozódnak fel. Több vizsgálat is arra a következtetésre jutott, hogy a ponty húsában található a legnagyobb geozminkoncentráció az édesvízi fajok közül. Ez összefüggésben van azzal a ténnyel, hogy a ponty az aljzatról és az iszapból kitúrva veszi fel táplálékát, ahol a legnagyobb a geozmint és MIB-et termelő mikroorganizmusok hányada (Papp és mtsai., 2007). 


\subsection{Mikotoxinok}

A halliszt iránti kereslet megnövekedése és ezen termék árának jelentős növekedése folytán a haltakarmányozásban előtérbe került a növényi fehérjék felhasználása azzal a céllal, hogy a hallisztet részben vagy egészben helyettesítse. Ez a jelenség azonban megnöveli annak a veszélyét, hogy a haltakarmányok mikotoxinokkal szennyeződjenek. A nyersanyagok és kész haltakarmányok mikotoxinokkal való szennyezettsége világszinten növekszik. A főbb mikotoxint tartalmazó nyersanyagok a következők: gabonafélék (búza, rizs), kukorica, szójaliszt és DDGS.

A mikotoxinok penészgombák által termelt másodlagos metabolitok, melyek rendkívül mérgezőek az állatok számára. Jelenleg több mint 400 különböző penészgombák általt termelt toxin ismert, melyek öt fó csoportba sorolhatók: aflatoxinok, ochratoxinok, fumonizinek, zearalenon és trichotecének (Santos és mtsai., 2010). A különböző mikotoxinok tenyészállatokra gyakorolt általános hatásai a csökkent növekedés és a romló immunstátusz. Emellett karcinogén, ösztrogenikus, neurotoxikus, nephrotoxikus, dermatotoxikus és immunszupresszív hatásuk is ismeretes.

A haltakarmányok különböző mikotoxinokkal való szennyezettsége a világon eltérő mértékü, más területeken más toxin jellemző. Az aflatoxinok jellemzően Afrikában, a zearalenon Észak-Ázsiában és egész Amerikában fordul elő legnagyobb mértékben. Dél-Afrikában a deoxinivalenol míg Dél-Ázsiában azochratoxin-A a legnagyobb számban előforduló toxin (Santos és mtsai., 2010).

A hazai pontycentrikus tógazdasági haltermelés takarmányozási céllal nagy mennyiségü gabonát használ fel. Emellett egyre növekszik a haltápok felhasználása is. A gabona nem megfelelő tárolása, illetve a tápok növényi összetevői mind növelik a mikotoxinnal való szennyezettség kockázatát, amit ki is mutattak: Európában a gabonaeredetű haltakarmányok jelentős része zearalenonnal és deoxinivalenollal szennyezett (Pietsch és mtsai., 2013).

A szennyezett tápok etetése jelentős minőségi és mennyiségi romlást okozhat azáltal a termelőnek, hogy a halak növekedése csökken, immunállapota romlik és a szaporítási eredmények is romolhatnak. Mindemellett élelmiszer-biztonsági kockázatot is jelenthet a fogyasztó számára a halhúsban felhalmozódott toxin, mely közvetlen hatással van a termék piacra kerülésére is. A különböző mikotoxinoknak az alábbi főbb hatásai vannak a homeotherm szervezetekre: karcinogenezis, teratogén hatás, ösztrogén mimetikus hatás, oxidatív stressz és az immunállapot romlása (Kovács, 2001; Marin és mtsai., 2011). Tehát a mikotoxinok a halhús elfogyasztásával az emberi szervezetbe kerülnek, ahol súlyos egészségi kockázatot jelenthetnek, így kiemelten fontos szerepet töltenek be a különböző akvakultúrákban elóállított termékek élelmiszer-biztonsági kérdéseinek vizsgálatakor.

\subsection{Növényvédő szerek}

$\mathrm{A} z$ intenzív mezőgazdasági tevékenység során a huszadik század közepétől kezdve jelentős mennyiségü növényvédő szert juttattak ki a környezetbe, amelynek egy része felhalmozódott a vízi ökoszisztémában is. Hazánkban a közelmúltban a „HappyFish” nevü projekt keretében több mint 400 peszticid és 100 gyógyszermaradvány vizsgálata történt meg a halastavak vizében, üledékében és a halak húsában. A többség esetében még vonatkozó jogszabályi határérték sincs jelenleg érvényben. Azok esetében azonban, ahol van rögzített határérték, ott a vizsgálat során az értékek minden esetben alatta maradtak, ám fontos megjegyezni, hogy a leggyakrabban és a legnagyobb mennyiségben a glifozát fordult elő a mintákban. A DDT nyoma még a rovarölő szer betiltását követően fél évszázad múltával is fellelhető (NAK, 2018).

Világszinten a legnagyobb mennyiségben a gyomirtók és a rovarölő szerek mutathatók ki vízből, iszapmintákból és halak szöveteiből is (Pazou és mtsai., 2006).

\subsection{Nehézfémek}

A világon sajnálatos módon még manapság is több helyen előfordul nehézfémmérgezés, ezért élelmiszer-biztonsági és élelmiszer-gazdasági szempontból fontos témakör. A leggyakrabban kadmium és higany okoz tüneteket az emberekben, és sok esetben összefüggés mutatható ki a mérgezés és a halfogyasztás között. A tengeri halak fogyasztása tekintetében például a nehézfémek jelenthetik a legnagyobb kockázatot az emberek számára. A legnagyobb menynyiségben az ólom, kadmium, arzén és a higany mutathatók ki a halak húsából. Toxikus mennyiségben fogyasztva ezek a nehézfémek és származékaik ártalmasak az emberi egészségre is (Bosch és mtsai., 2016), így kiemelten fontos, hogy a fogyasztók számára elérhető termékekben azok ne kerüljenek be.

A nehézfémek közül ki kell emelni a higanyt, melynek koncentrációja egyre emelkedik a világóceánban az emberi tevékenység hatására. A vízi ökoszisztémába kerülő szervetlen higany elsősorban mikrobiológiai folyamatok hatására szerves metil-higannyá konvertálódik, amely erős idegméreg, és a táplálékláncban felfelé haladva a koncentrációja egyre emelkedik (Chalmers, 2004). Az összes higany több mint 95\%-a metil-higany formájában van jelen a halak és vízi gerinctelenek ehető részeiben (Howgate, 1998).

A hazai tógazdaságokban is kimutathatók a nehézfémek az üledék-, zooplankton- és halhúsmintákból is, ám egy esetben sem érik el a megengedett határértéket. Biohaltermeléssel bizonyítottan csökkenthető a halhús nehézfémtartalma (Bíróné Oncsik és mtsai., 2010).

Míg az európai tógazdasági halak alapvetően nem tartalmaznak jelentős mennyiségű nehézfémet, addig például a Duna alsó szakaszán az emberi tevékenységek következtében jelentős nehézfém-felhamozódás tapasztalható $(\mathrm{Cd}, \mathrm{Hg}, \mathrm{Cu}, \mathrm{Pb})$, leginkább a dunai hering (Alosa immaculata) szervezetében (Simionov és mtsai., 2016).

\subsection{Megbetegedések}

A halakat fertőző kórokozók alapvetően nem jelentenek kockázatot az emberi egészségre. Azonban a halak szervezete és a vízi környezet sok olyan kórokozót (legfóképpen baktériumot) tartalmazhat, mely komoly egészségügyi kockázatot (zoonózis) jelenthet humán vonatkozásban (Baska és mtsai., 2018). Ezek közül is általában a trópusi halfajok hordozhatnak nagyobb hányadban olyan kórokozókat, melyek az emberre is veszélyesek, mert ezek kedvelik a magasabb hőmérsékletet. A mérsékelt éghajlat és a halak változó (relatíve alacsony) testhőmérséklete nem kedvez a legtöbb baktérium proliferációjának (MacMillan, 2001).

A fejlődő országokban jelentős mennyiségü kommunális szenynyvíz jut tisztítatlanul az élővizekbe (folyók, tenger) és akár halastavakba is. Egyes vizsgálatok szerint $103 / \mathrm{ml}$ összcsíraszám felett egyes kórokozók (E. coli, Salmonella sp.) bejutnak a halak emésztörendszerébe és szöveteibe (Howgate, 1998). Az állati ürülék is jelenthet kockázatot, amennyiben a trágya nem érett formában, hanem kezeletlenül kerül bele a halastavakba tápanyag-utánpótlás céljából. 
Friss, komposztálatlan baromfitrágya Salmonella baktériummal szennyezheti a halastavakat, a kezeletlen sertéstrágya pedig orbánc (Erysipelothrix rbusiopathiae) fertőzést idézhet elö, illetve nagyobb mennyiségben tartalmazhatja egyes féregparaziták (Ascaris és Trichuris spp.) petéjét. Ezen élősködők mindegyike előfordul mérsékelt égövön, ám komoly mértékü és kiterjedésű fertőzéseket a trópusokon képes okozni a magasabb hőmérséklet és a rossz higiénés viszonyok miatt.

Hazai viszonylatban megjelenő főbb zoonózisok a „vízi rühösség" és a halgümőkór. Ezek nem élelmiszer-biztonsági, hanem inkább munkaegészségügyi kockázatot jelentenek az emberekre nézve. Rühösség alakulhat ki, ha az ember bőre érintkezik a fertőzött vízzel, és a bőr sérülésein keresztül a mételyek cerkáriái bejutnak a szövetekbe. Ezek általában a madarakat vagy kérődzőket betegítik meg, mert ezek a végleges gazdái, és bennük alakulnak ki a kifejlett szaporodóképes egyedek. Emberben a folyamat abortív, vagyis a parazita elhal, csak helyi gyulladásos-allergiás reakciót vált ki.

A halgümőkór az egyetlen halakat megbetegítő mycobacterium, mely a lehủlt felázott emberi bőrben is képes megbetegedést elöidézni. Tipikusan halászok betegsége, mely orvosi beavatkozást igényel (Baska és mtsai., 2018).

Élelmiszer-biztonsági és élelmiszer-gazdasági szempontból két baktérium, illetve az általuk okozott megbetegedések kiemelendők az akvakultúra vonatkozásában. Egyikük a Listeria spp. és az általa okozott listeriosis. A Listeria monocytogenes baktérium széles körben előfordul a talajban és a vizekben is, elsősorban a nyersen fogyasztott vagy nem kellően hőkezelt halak és tengeri ételek fertőznek. Ezenkívül nagy számban történik megbetegedés mosatlan zöldség és gyümölcs, valamint rosszul elkészített töltelékáru fogyasztása útján is. Hányás, hasmenés és fejfájás jellemzi, szövődményei során agyhártyagyulladás és szepszis is kialakulhat. Kiemelten veszélyes várandós nőkre, kisgyerekekre és immunhiányos állapotban szenvedőkre (Harper, 2002). Megfelelő hőkezeléssel megelőzhető.

Másik jelentős veszélyforrást a Clostridium botulinum baktérium okozza. Ez egy Gram-pozitív anaerob baktérium, mely elterjedt az édesvizekben és az iszapban is. Maga a baktérium nem fertőző, azonban egy fehérjetoxint (botulin toxin) termel, mely az ismert mérgek közül az egyik legerősebb idegméreg. Halak bélrendszeréből nagy számban kimutatható. A baktérium endospórái nagyon ellenállók, csak $120{ }^{\circ} \mathrm{C}$-on pusztíthatók el, minimum 5 perces behatást követően. A toxin kevésbé hőálló, $80{ }^{\circ} \mathrm{C}$ felett bomlik (Inglis és mtsai., 1993).

Főképpenezakét kórokozótehetőfelelősséazért, hogyazélelmiszer-eredetű megbetegedések jelentős részéért a halak és egyéb vízi állatok felelősek például az Egyesült Államokban (Nickelson, 1998).

\section{AZ AKVAPÓNIA ÉLELMISZER-BIZTONSÁGI SA- JÁTOSSÁGAI}

$\mathrm{A} z$ emberi fogyasztásra szánt élelmiszerek biztonságosabbá és egészségesebbé tétele világszerte egyre jelentősebbé válik. Az akvapónia számos pozitív aspektusa ellenére magában hordoz élelmiszer-biztonsági kockázatot abban a tekintetben, hogy a víz, melyben a halak élnek, közvetlen kapcsolatba kerül a termesztett növényekkel és azok ehető részeivel. Ugyanez igaz az összes integrált termelési rendszerre. Az akvapónia jelenleg elterjedőben lévő élelmiszer-termelő rendszer, nagyon kevés tudományos igényü információ áll rendelkezésre élelmiszer-biztonsági szempontból.
Más megközelítésből pedig az akvapónia relatíve biztonságos állati és növényi eredetű élelmiszereket képes elöállítani környezetbarát módon, akár városias környezetben, rendelkezésre álló termőtalaj nélkül is, mivel a halürüléket leszámítva sem trágya, sem pedig egyéb vegyszer nem kerül a rendszerbe (Azad és mtsai., 2016). $\mathrm{A} z$ akvapónia zárt rendszer, ezáltal sokkal kevésbé kitett olyan környezeti tényezőknek, mint az élővizek és a tógazdaságok. A környezetszennyezésből származó veszélyes anyagok (pl.: nehézfémek és gyógyszermaradványok), valamint az állati trágyából származó kórokozók minimális eséllyel akkumulálódhatnak a rendszerben.

\subsection{Kórokozók}

Megfelelő körültekintéssel az akvapónia az egyik legbiztonságosabb élelmiszer-termelő rendszer. Ennek fő oka, hogy az akvapónia működéséhez és fenntartásához nélkülözhetetlen hasznos baktériumflóra egyfajta természetes védelmet jelent a patogénekkel szemben (Fox, 2012).

$\mathrm{Az}$ alábbi patogének azonban kockázatot jelenthetnek az akvapóniás termelési rendszerekben: E. coli, Vibrio spp., Aeromonas spp., Streptococcus spp., Erysipelothrix rbusiopatbiae, Shigella spp., Campylobacter spp., Pleisomonal shigelloides, Edwardsiella tarda és Cryptosporidium (Ljubojevic, 2017).

Élelmiszer-biztonsági kockázatot jelentő kórokozók a telepített halakkal és a vízzel kerülhetnek be legnagyobb eséllyel. A víz sok esetben lehet forrása az E. coli, Salmonella spp., Vibrio cholera, Shigella spp. baktériumoknak és a Cryptosporidium, valamint Girdia lamblia parazitáknak (Ljubojevic, 2017). A víz patogéntartalma megfelelő fertőtlenítési eljárásokkal csökkenthető, azonban ez elpusztíthatja a rendszer müködéséhez elengedhetetlen nitrifikáló baktériumok egy részét is. Az egyik leghatékonyabb módszer a patogén csíraszám csökkentésére a víz UV-sterilizációja. Ez amellett, hogy csökkenti egyes kórokozók denzitását az akvapóniában, nem okoz semmilyen kemikáliaakkumulációt a halak és a növények szöveteiben (Patillo és mtsai., 2018).

Újabban kimutatták, hogy a Listeria monocytogenes baktérium képes a római saláta szöveteibe internalizálódni (Shenoy és mtsai., 2017). Ez a tény felveti a lehetőségét, hogy a halakon és a vízen kívül az akvapóniába ültetett növények is hordozhatnak olyan kórokozókat, melyek veszélyesek lehetnek az emberi egészségre.

Harmadik lehetséges forrása a patogéneknek maga az ember. Beteg vagy betegséget hordozó munkás baktériumok és vírusok széles körét (Hepatitis A, Salmonella typhi, Shigella spp., Norwalk vírus, Staphylococcus aureus, Streptococcus pyogenes) képes átvinni az akvapóniarendszerre (Chalmers, 2004). Ezért kiemelten fontos a megfelelő higiénés körülmények biztosítása és az előírások pontos betartása a rendszer üzemeltetésekor (pl.: beteg alkalmazottak mellőzése, kézmosás stb.).

\subsection{Nitráttartalom}

A különböző zöldségfélék, de különösképpen a levélzöldségek jelentős mennyiségben képesek akkumulálni a nitrátot, mely jelentős kockázatot jelent az emberi egészségre. A 20. század második felében került a táplálkozástudománnyal foglalkozó szakemberek látókörébe az élelmiszerekben előforduló nitrát. Ekkor bizonyosodott be ugyanis, hogy számos csecsemő halála ezzel hozható összefüggésbe.

$\mathrm{A} z$ anyagcsere folyamán a nitrát a vizelettel kiürül. A nitrát a tárolás során átalakul nitritté, mely folyamat az ember emésztő- 
rendszerében tovább folytatódik és meggyorsul. A nitrit erős méreg. Egyrészt a hemoglobinhoz kapcsolódva meggátolja annak oxigénszállító képességét, másrészt szekunder aminokkal karcinogén hatású nitrozaminokat képez (Gillingerné Pankotai, 2005).

A nitrát felhalmozódásának mértékét a növényekben alapvetően két dolog befolyásolja: az évszak és a termesztéstechnológia. Alapvetően elmondható a levélzöldségekről, hogy a napfényes időszakban alacsonyabb, őszi-tavaszi, valamint borús időben jelentősen magasabb a növények nitráttartalma.

Termesztéstechnológiai tekintetben az intenzifikációval és a mütrágyahasználattal egyenes arányban növekszik a növények nitráttartalma. Több kutatás is rávilágított, hogy a szerves trágya és az ökológiai gazdálkodás jelentősen határérték alatt tudja tartani a nitrátkoncentrációt.

$\mathrm{A} z$ akvapóniás növénytermesztés alapvetően nem használ kemikáliákat és mütrágyát, ezért a hagyományos szabadföldi és szerves trágyát alkalmazó gazdálkodással vonható párhuzamba e tekintetben. Az akvapóniában nevelt saláta (Lactuca sativa) jelentősen kevesebb nitrátot tartalmaz, szemben a mesterséges tápoldatokat alkalmazó hidropóniás technológiával elóállított salátával. Míg az akvapóniás saláta $2400 \mathrm{mg} / \mathrm{kg}$ alatti értéken marad (Rico-Garcia és mtsai., 2009), addig az intenzíven hajtatott saláta nitráttartalma akár $5500 \mathrm{mg} / \mathrm{kg}$ is lehet (Tosun E Ustun, 2004). Blidariu és mtsai (2013) az akvapóniában nevelt salátában mindösszesen $810 \mathrm{mg} / \mathrm{kg}$ nitráttartalmat mértek. A 17/1999. (VI. 16.) EüM rendelet alapján a téli időszakban üvegházban nevelt saláta megengedett nitráttartalma $4500 \mathrm{mg} / \mathrm{kg}$, a nyári időszakban szabadföldön nevelté pedig maximum $2500 \mathrm{mg} / \mathrm{kg}$ lehet.

$\mathrm{A} z$ akvapóniarendszerben nevelt zöldségek alacsonyabb nitráttartalmuknál fogva egészségesebbek a fogyasztók számára az intenzíven hajtatott zöldségféléknél.

\subsection{Emberi tényezők és jó gyakorlatok}

Jelenleg nincs hivatalosan elfogadott követelményrendszer és elöírás az akvapóniás termelők számára. Az Akvapónia Szövetség (USA) összeállított egy ideiglenes Jó Mezőgazdasági Gyakorlatok (GAP) kiadványt akvapóniára adaptálva, azonban ez a dokumentum nem hivatalosan elfogadott, és fejlesztésre szorul. Emellett az USDA is készít jelenleg egy akvapónia GAP standard kiadványt, mely a 2018 év végéig társadalmi és szakmai egyeztetés alatt állt, és a végső hivatalos dokumentum várhatóan 2020-ban fog elkészülni (USDA, 2018).

Élelmiszer-biztonsági szempontból az egyik legnagyobb veszélyt az ember jelenti az akvapóniás termelésre. Az alapvető higiénia, a betakarítás és a napi gondozási feladatok, a víz és a halak származása mind az üzemeltetőn múlik, és nagyban hozzájárul az előállított termék minőségéhez és megbízhatóságához.

Higiéniai szempontból nagyon fontos, hogy minden esetben mosson kezet a termelö, amikor a termesztőegységgel foglalkozik, mivel a patogén csírák legnagyobb eséllyel az emberi érintéssel kerülhetnek be az akvapóniába. Kiemelten fontos a halas és növényes egységek közötti kézfertőtlenítés. A termesztőközeghez lehetőség szerint gumikesztyűvel nyúljon a felhasználó (Hollyer és mtsai,, 2009).

A Hawaii University kiadványa alapján az alábbi főbb előírások fogalmazhatók meg az akvapóniás jó gyakorlatok tekintetében $(\mathrm{CTAHR}, n d)$ :
+ mosdó/WC elhelyezése 400 méteren belül,

+ csapvizes kézmosó, folyékony szappan és egyszer használatos papírtörlő, valamint fedeles szemetesláda biztosítása,

+ tilos a dohányzás és az étkezés a termelő- és csomagolóegység közelében,

+ betakarítási eszközök folyamatos tisztán tartása,

+ folyamatos kártevők elleni védelem,

+ folyamatos vízminőségi és halegészségügyi monitoring.

A fenti általános érvényű ajánlásokon kívül az élelmiszer-termelésre és -feldolgozásra vonatkozó országonkénti szabályozást kell alkalmazni.

Az akvapónia GAP bevezetésével és következetes használatával jelentős mértékben csökkenthető az élelmiszer-biztonsági kockázat, valamint növelhető a fogyasztók bizalma, a bevétel, és jelentősen csökkenthetők a kiadások és az időráfordítás a potenciálisan elkövetett hibák kiküszöbölése miatt (Hollyer és mtsai., 2009).

\section{KÖVETKEZTETÉSEK}

A z élelmiszer-biztonság minden esetben a termelés helyén kezdődik, legyen az a szántóföld, állattartó telep vagy éppen egy akvapóniarendszer. Az élelmiszerlánc során a termelést, feldolgozást, szállítást és értékesítést végzők, valamint a fogyasztók is jelentős hatással vannak az élelmiszer-biztonságra. Az akvapóniás termeléssel foglalkozó személyeknek komoly felelössége van abban a tekintetben, hogy a termelt állati és növényi eredetű termék egészséges és biztonságos legyen.

Jelenleg csak nagyon kevés információ áll rendelkezésre az akvapóniát érintő élelmiszer-biztonsági kérdésekben a nemzetközi szakirodalomban. Az biztosan állítható, hogy az akvapóniával alapvetően biztonságosabb élelmiszert állíthatunk elő, mint a tógazdasági termeléssel és a konvencionális vagy intenzív hidrokultúrás növénytermesztéssel. Ennek fó okai a vegyszerek, mütrágyák és egyéb kemikáliák, valamint a gabonatakarmányozás mellőzése. Így a növényekben alapvetően esélytelen a szermaradványok, és a túlzott nitrát akkumuláció, a halakban pedig minimálisra csökkenthető példának okáért a mikotoxinok mennyisége. A müködési mechanizmusából kifolyólag azonban potenciálisan pár élelmiszer-biztonsági kockázati tényezőt is hordozhat magában. Az akvapóniarendszerek üzemeltetése nemcsak termeléskori előnyt jelenthet a gazdálkodók/üzemeltetők számára, hanem a termék piacra jutásakor is jelentkezhetnek pozitív hatások, hiszen az élelmiszer-biztonsági szempontból kisebb kockázatot jelentő termelésből származó termékek a fogyasztók számára is vonzóbbak lehetnek.

Nagyon fontos cél a közeljövőben, hogy minél több kutatás térjen ki azoknak a tényezőknek a vizsgálatára, melyek befolyásolhatják az akvapóniarendszerekben előállított termékek minőségét. A tudományos eredmények és a termelök szakmai tapasztalatai alapján pedig elengedhetetlen a jó gyakorlatok megfogalmazása és a kötelező érvényű szabályrendszerek megalkotása.

\section{6. ÖSSZEFOGLALÁS}

Az emberiség történelme folyamán a Föld erőforrásai nagyban függtek a különböző kultúráktól, azok fejlettségétől és korlátozó tényezőiktől. 
A huszadik század kezdete óta tapasztalható demográfiai robbanásnak köszönhetően jelenleg a Föld népessége meghaladja a 7,3 milliárdot. A természeti erőforrások felhasználása az 1970-es évektől olyan mértékű, hogy meghaladja a fenntartható szintet. A környezetet és emberi egészséget érintő aggodalmak és a folyamatosan növekvő igények kihívás elé állítják a mezőgazdaságot és az élelmiszer-termelést is. A halak és növények termelését integrálni képes akvapónia új perspektívát jelent a hagyományos és városi termelők számára a termelékenység növelésében a talajhasználat mellőzésével. Ennek köszönhetően az akvapóniarendszerek potenciálisan beilleszthetők a rövid élelmiszer-ellátási láncokba is. Azonban azélelmiszer-biztonsági kockázat növekszik, amennyiben a növénytermesztés a halak egyidejü jelenlétével párosul. A tanulmány az akvapóniára vonatkozó alapvető élelmiszer-biztonsági tényezőket vizsgálja.

\section{KÖSZÖNETNYILVÁNÍTÁS}

Ez a tanulmány a EFOP-3.6.1-16-2016-00007 „Intelligens szakosodási program a Kaposvári Egyetemen" kutatás keretében született.

\section{IRODALOM}

AKI. (2018). Az egy főre jutó halfogyasztás alakulása 20142017. Budapest: Agrárgazdasági Kutató intézet.

Azad, K. N., Salam, M. \& Azad, K. N. (2016). Aquaponics in Bangladesh: current status and future prospects. Journal of Bioscience and Agriculture Research, 7(2), 669-677. doi: 10.18801/ jbar.070216.79

Baska, B. F., Bozánné Békefi, E. \& Sziráki. (2018). Halegészségügy, halbetegségek. Budapest: Nemzeti Agrárgazdasági Kamara.

Bíróné Oncsik, M., Hegedűs, R., Józsa, V. \& Györe, K. (2010). Szervetlen mikroszennyező komponensek összehasonlító vizsgálata sekély vizű halastóban és völgyzárógátas horgásztóban. [Konferencia-előadás ppt-je] HAKI. Letöltés dátuma: 2019. 01. 29. forrás: http://hakinapok.haki.hu/images/stories/0505_Birone.pdf

Blidariu, F., Radulov, I., Lalescu, D., Drasovean, A. \& Grozea, A. (2013). Evaluation of Nitrate Level in Green Lettuce Conventional. Animal Science and Biotechnologies, 46(1), 244-250.

Bojtárné-Lukacsik, M. \& György, Á. (2016). Magyarország haltermelése és perspektívái a számok tükrében. In Karlovitz J. T. (szerk.) Társadalom, kulturális háttér, gazdaság: IV. IRI Társadalomtudományi Konferencia. (pp. 126-131). Komárno: International Research Institute (2016),

Bosch, A., O’Neill, B., Sigge, G., Kerwath, S. \& Hoffman, L. (2016). Heavy metals in marine fish meat and consumer health: a review. J Sci Food Agric, 96(1), 32-48. doi* 10.1002/jsfa.7360

Chalmers, G. (2004). Aquaponics and Food Safety. Lethbridge Alberta Canada.

CTAHR. (nd). Get your farm on GAP! Good Agricultural Practices. Letöltés dátuma: 2019. 03. 21. forrás: http://manoa. hawaii.edu/ctahr/farmfoodsafety/

Engle, C. R. (2015). Economics of aquaponics. Southern Regional Aquaculture Center, 1-4.

Gerber, N. N. \& Lechevalier, H. A. (1965). Geosmin, an earthy smelling substance isolated from actinomycetes. Applied Mic- robiology, 13(6), 935-938. doi: 10.1128/aem.13.6.935-938.1965

Gillinerné Pankotai, M. (2005). A salátafélék nitráttartalma. Biokultúra, 16(5), 27-28.

Harper, C. (2002). Food-borne pathogens of aquatic species. Aquaculture Magazine, 49-52.

Hollyer, J., Tamaru, C., Riggs, A., KlingerBowen, R., Howerton, R., Okimoto, D. \& Martinez, G. (2009). On-Farm Food Safety: Aquaponics. Food Safety and Technology, 2009/July FST-38. $1-7$.

Howgate, P. (1998). Review of the public health safety of products from aquaculture. Intermational Journal of Food Science and Technology, 33(2), 99-125. doi: 10.1046/j.13652621.1998.3320099.x

Inglis, V., Roberts, V. \& Bromage, N. (1993). Bacterial Diseases of Fish. Toronto: John Wiley and Sons Inc.

Kerepeczki É, Lengyel P, Bodea T., Szabó P., Csengeri I. \& Pekár F. (2000). A víz és a halhús minőségét befolyásoló íz- és szagrontó anyagok vizsgálata. I. Képződés, beépülés, felhalmozódás, kiürülés, kezelés. Halászatfejlesztés, 24, 145-151.

Kovács, F. (2001). Penészgombák-mikotoxinok a táplálékláncban. Budapest: Magyar Tudományos Akadémia.

$\mathrm{KSH}$. (2018). A rednelkezésre álló élelmiszer és tápanyag egy före jutó mennyisége (1990-). Letöltés dátuma: 2019. 01. 25. forrás: https://www.ksh.hu/docs/hun/xstadat/xstadat_eves/i_ qpt011b.html

Ljubojević, D. P. (2017). Food safety hazards related to fish produced in aquaponics. In Dubrovnik: Aquaculture Europe 2017. (pp. 676-677.) Letöltés dátuma: 2019. 01. 19. forrás: EAS Online: https://www.was.org/easonline/AbstractDetail. aspx?i=8594

Lovell, R. T., Lelana, I. Y., Boyd, C. E. \& Armstrong, M. S. (1986). Geosmin and musty muddy flavors in pond-raised channel catfish. Transactions of the American Fisheries Society, 115(3), 485-489. doi: 10.1577/1548-8659(1986) $115<485$ : gamfip $>2.0$. $\underline{\mathrm{co} ; 2}$

MacMillan, J. (2001). Aquaculture and antibiotic resistance: a negligible public health risk? World Aquacult, 32(2), 49-51.

Marin, D., Taranu, I., Burlacu, R., Manda, G., Motiu, M., Neagoe, I. \& Calin, L. (2011). Effects of zearalenone and its derivatives on porcine immune response. Toxicology in Vitro, 25(8), 1981-1988. doi: 10.1016/j.tiv.2011.06.022

NAK. (2018). Növekvőben a hazai haltermelés. Letöltés dátuma: 2019. 03. 12. forrás: http://nak.hu/agazati-hirek/mezogazdasag/147-allattenyesztes/98421-novekedoben-a-hazai-haltermeles

Nickelson, R. (1998). The quality and safety of aquacultured foods. World Aquaculture, 29(1), 60-62.

Papp Zs., Kerepeczki É., Pekár F. \& Gál D. (2007). Natural origins of off-flavours in fish related to feeding habits. Water Science and Technology, 55(5), 301-309. doi: 10.2166/wst.2007.192

Patillo, A., Shaw, A., Currey, C., Xie, K. \& Rosentarter, K. (2018). Efficacy of UV-sterilization in reducing foodborne pathogens in aquaponics system. Iowa: Iowa State Uninersity.

Pazou, E., Laleye, P., Boko, M. \& van Gestel, C. (2006). Contamination of fish by organochlorine pesticide residues in the Ouémé River catchment in the Republic of Bénin. Environment International, 32(5), 594-599. doi: 10.1016/j.envint.2006.01.003 
Pietsch, C., Kersten, S., Burkhardt-Holm, P., Valenta, H. \& Dänicke, S. (2013). Occurrence of Deoxynivalenol and Zearalenone in Commercial Fish Feed: An Initial Study. Toxins, 5(1), 184192. doi: 10.3390/toxins5010184

Rakocy, J. E. (2012). Aquaponics: integrating fish and plant culture. Aquaculture Production Systems, 343-386. doi: 10.1002/9781118250105.ch14

Rico Garcia, E., Casanova Villareal, V., Mercado Luna, A., Soto Zarazua, G., Guevara Gonzalez, R., Herrera Ruiz, G. \& Velazquez Ocampo, R. (2009). Nitrate Content on Summer Lettuce Production Using Fish Culture Water. Trends in Agricultural Economics, 2(1), 1-9. doi: 10.3923/tae.2009.1.9

Santos, G., Rodrigues, I., Naehrer, K. \& Encarnacao, P. (2010). Mycotoxins in aquqculture: Occurence in feed components and impact on animal performance. Aquculture Europe, 35, $6-10$.

Shenoy, A. G., Oliver, H. F. \& Deering, A. J. (2018). Listeria monocytogenes Internalizes in Romaine Lettuce Grown in Greenhouse Conditions. Journal of Food Protection, 80(4), 573-581. doi: 10.4315/0362-028x.jfp-16-095
Simionov, I., Cristea, V., Stefan, P. \& Bocioc, E. (2016). The presence of heavy metals in fish meat from Danube River: an overview. AACL Bioflux, 9(1), 1388-1399.

Somerville, C., Cohen, M., Pantanella, E., Stankus, A. \& Lovatelli, A. (2014). Small-scale aquaponic food production: integrated fish and plant farming. FAO Fisheries and Aquaculture Technical Paper. FAO.

Tosun, I. \& Uston, N. S. (2004). Nitrate content of lettuce grown in the greenhouse. Bulletion Environmental Contamination and Toxicology, 72(1), 109-113. doi: https://doi.org/10.1007/ s00128-003-0247-2

USDA. (2018). Aquaponics Good Agricultural Practices Pilot. Washington: USDA.

Van der Ploeg, M. \& Tucker, C. S. (1993). Seasonal trends in flavor quality of channel catfish, (Ictalurus punctatus) from commercial ponds in Mississippi. Journal of Applied Aquaculture, 3(1-2), 121-140. doi: 10.1300/j028v03n01 10 